\title{
Экзотизация как познание: усинские старообрядцы и оптики дореволюционных этнографических описаний религиозных сообществ
}

\author{
Данила С. Рыговский \\ Университет Тарту, Эстония
}

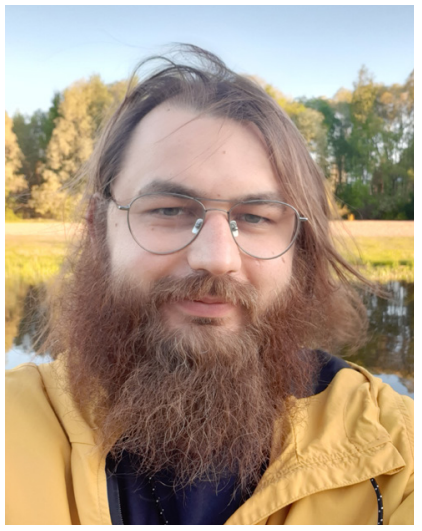

В статье анализируется тема конструирования идентичности и экзотизации старообрядиев, основавщих поселения на реке Ус (территории Урянхайского края, ныне входит в Красноярский край, Россия), в этнографических работах четырёх авторов: И. А. Пуговкина, Н. А. Путилова, А. В. Адрианова и Ф. Я. Кона. Старообрядцы переселяются сюда в 1860-е г2. на приграничную территорию между Россией и Китаем, в места кочёвок тувинцев. Вместе с появлением общины начинает формироваться и понятие Усинского края.

Опираясь на концепцию внутренней колонизации, автор предлагает анализ идеологических элементов, скрытых в структуре этнографического описания конфессиональных сообществ. Старообрядцы представляли большой интерес для этнографов. Однако авторы излагали свой опыт взаимодействия с ними предвзято, в том смысле, что их повествования не были свободны от идеологий и стереотипов, сложившихся в дореволюционной литературе.

Н. А. Путилов, православный миссионер и священник, с помощью своих обширных сочинений пытался показать епархиальному начальству трудности своей жизни среди «раскольников». Излагая факты, Путилов упирал на то, что давно живёт на Усу и хорошо знаком с историей и текущим положением старообрядческой общины. Однако ему приходилось оправдывать свои неудачи дурными нравами староверов. И. А. Пуговкин был представителем белокриницкого согласия, и усинские старообрядиы его также интересовали как потенциальная паства. Его текст - это, скорее, указатель заблуждений, царивших в усинской общине без достойного духовного руководства. А. В. Адрианов и Ф. Я. Кон были профессиональными этнографами. Первый в своём коротком очерке солидарен с мнением И. А. Пуговкина и, в целом, опирается на его работу. При этом оба жёстко критикуют деятельность Путилова. Работа Кона по своему маситабу и структуре напоминает труд Путилова, однако Кон относится к сочинению последнего, скорее, как к одному из источников, причём не самому объективному. В целом исследование Кона следует рассматривать как попытку конструирования объекта этнографического описания Усинского края, что было связано с колонизацией Южной Сибири.

Ключевые слова: старообрядиы; внутренняя колонизация; этнографическое описание; экзотизация; Усинский край; Красноярский край; Тува; Урянхайский край; Н. А. Путилов; Иван Алексеевич Пуговкин; Александр Васильевич Адрианов, Феликс Яковлевич Кон

Исследование было поддержано грантом Исследовательского Совета Эстонии (PRG670).

Для циитирования:

Рыговский Д. С. Экзотизация как познание: усинские старообрядцы и оптики дореволюционных этнографических описаний религиозных сообществ // Новые исследования Тувы. 2021, № 3. C. 111-127. DOI: https://www.doi. org/10.25178/nit.2021.3.9

Рыговский Данила Сергеевич - докторант кафедры эстонского и компаративного фольклора Университета Тарту. Адрес: 51003, Эстония, г. Тарту, ул. Юликооли, д. 16. Тел.: +3727375223. Эл. адрес: danielrygovsky@gmail.com. Научный руководитель: лектор, PhD Эрго-Харт Вястрик.

RYGOVSKIY, Danila Sergeevich, Doctoral student, Department of Estonian and Comparative Folklore, University of Tartu. Postal address: 51003, Estonia, Tartu, Ülikooli 16. Tel.: +3727375223. Email: danielrygovsky@gmail.com. Supervisor: lecturer, PhD ErgoHart Västrik. 


\title{
Othering as Perception: Old Believers of Us and Perspectives of Pre-Revolutionary Ethnographic Descriptions of Religious Communities
}

\author{
Danila S. Rygovskii \\ University of Tartu, Estonia
}

\begin{abstract}
This paper focuses on making of identity and othering of Old Believers, who founded settlements on the river Us (currently assigned to Krasnoyarsk krai), in ethnographical works by I. A. Pugovkin, N. A. Putilov, A. V. Adrianov, and F. Ya. Kon. Old Believers resettled behind the Sayan Mountains in 1860s at the Russia-China border, in the area of Tuvan seasonal migrations. The emergence of a community there brought about a notion of the Usinskii krai.

Drawing on the conception of internal colonization I offer an analysis of ideological elements hidden in the structure of ethnographic descriptions of religious groups. Old Believers were at the center of attention of ethnographers. However, many authors presented their experience of interaction with Old Believers in a prejudiced way - in the sense that their narrative was not free from ideological bias and stereotypes typical for pre-revolutionary literature.

As an Orthodox missionary and priest, N. A. Putilov used his writings to prove difficulties of living among "the Schismatics" to his diocesan authorities. While stating his facts, Putilov claimed that he lived on the Us for a long time and was quite familiar with the history and current situation of the Old Believer community. However, he had to find excuses for his failures by the supposed bad morals of the Old Believers. I. A. Pugovkin belonged to the Belokrinitskoe accord, and was thus also interested in the Old Believers of Us as potential flock. His text gives an impression of a recitation of misbeliefs which overwhelmed the community of Us without a proper spiritual guidance. A. V. Adrianov and F. Ya. Kon were professional ethnographers. In his short essay, the former expressed solidarity with Pugovkin's opinion and largely relied on his work in general while severely criticizing Putilov's actions. Kon's work resembles Putilov's in scope and structure, but Kon rather perceives the essay of the latter as one of the sources, and not the most reliable one. In general, Kon's study should be regarded as an attempt at making the Usinskii krai an object of ethnographic description, linked to the colonization of Sothern Siberia.
\end{abstract}

Keywords: Old Believers; internal colonization; ethnographic description; othering; Usinskii krai; Krasnoyarsk krai; N. A. Putilov; Ivan Alekseevich Pugovkin; Aleksandr Vasilievich Adrianov; Feliks Yakovlevich Kon

Financing:

The study was supported by a grant from the Research Council of Estonia (PRG670).

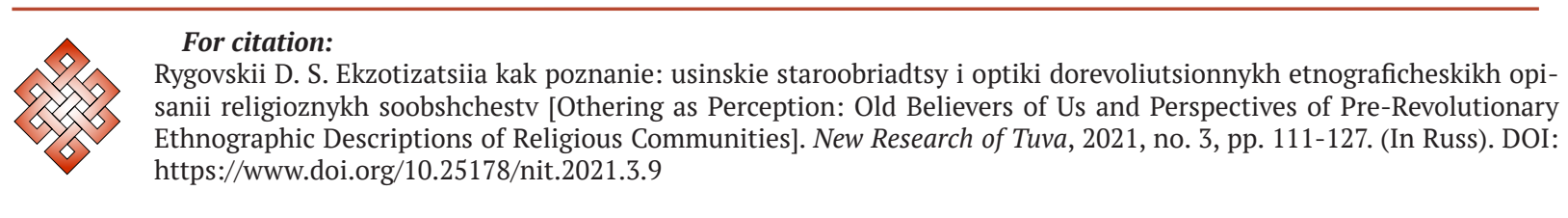

\section{Введение}

Парадокс интеллектуального интереса к старообрядчеству в Российской Империи заключается в том, что несмотря на обширную литературу, он не находит продолжения в общественных дисциплинах: своей «Протестантской этики» (Weber, 1997) на отечественной почве не появляется1. Лишь в последнее десятилетие Д. Е. Расков, В. В. Керов и другие авторы начнут писать о мировоззренческих особенностях старообрядчества, которые позволили ему активно включиться в капиталистическую формацию и способствовать её развитию в России (Керов, 2010, 2016; Расков, 2012; Уэст, 2010).

Дореволюционную литературу о старообрядцах принято делить на два направления: так называемые, синодальную историографию и демократическую². В первом случае, авторами выступали представители официальной, Греко-Православной Церкви, такие как, например, митрополит Ростовский Димитрий с его знаменитым «Розыском о раскольнической Брынской вере» (1855)3. Несмотря на пре-

${ }^{1}$ Однако православию находится место в научном творчестве М. Вебера, он активно интересовался русским мистицизмом, а в конце жизни даже хотел заняться исследованием русского сектантства (Эткинд, 1998: 22-23).

${ }^{2}$ См.: Гурьянова, 1988: 8.

${ }^{3}$ Ростовский Димитрий. Розыск о раскольнической брынской вере. М.: Типография Синода, 1855. 643 с. 
тенциозность, этнографические записи занимали важное место в синодальной историографии. В частности, это относится к донесениям и очеркам православных миссионеров, которые на протяжении долгого времени контактировали со старообрядцами и в силу своих обязанностей были хорошо знакомы с богословскими основами вероучений и обрядностью последних.

Демократическое направление составляли светские общественно-политические деятели и профессиональные этнографы. Такие авторы видели в старообрядцах, прежде всего, живой пример сохранившихся, но в силу исторических причин оставшихся в тени, национальных демократических начал: так А. П. Щапов видел в «расколе» следы земства (Щапов, 1862). Этнография была призвана добавить конкретики к описаниям различных старообрядческих групп. Однако, как и в работах синодального направления, в этнографических исследованиях встречается довольно много оценочных суждений. Я проиллюстрирую это цитатой из статьи исследовательницы алтайского старообрядчества М. В. Швецовой:

«Более образованные слои русского общества понимали необходимость церковной реформы, но огромная масса населения, остававшаяся невежественной и сохранившая в значительной степени языческие воззрения наряду с христианскими, воспринявшая в большинстве только одну внешнюю, обрядовую сторону христианства, именно этой стороне и придавала значение, тогда как дух новой религии был ей совершенно недоступен. Понятно, что исправление церковных книг, перемена “двуперстного сложения” на “трехперстное” и другие чисто внешние изменения казались ей переменой самой религии, изменой “истинной вере Христовой”, почему более энергичные и религиозные люди из ее среды выступили против этих “новшеств” с резким протестом и увлекли за собой толпу» (Швецова, 1899: 41).

Эта выдержка из работы Швецовой отражает ту идеологию, на которой базировалась дореволюционная этнография религиозных групп: то, что говорили исследователям их собеседники, явно не совпадало с религиозным опытом первых. Они не могли в полной мере понять, что именно хотят сказать старообрядцы. Видя лишь противоречия и заблуждения в их словах, этнографы объясняли это с позиции власти ${ }^{1}-$ невежеством верующей массы.

Тем не менее, исследовательская работа часто имела продолжение в художественном тексте, очевидным примером чего является дилогия П. И. Мельникова-Печерского «В лесах» (1871-1874) и «На горах» (1875-1881)2. Локальные традиции староверов давали авторам как этнографических заметок, так и литературных произведений (иногда это были одни и те же люди) идеи для ярких персонажей, материал для описаний обрядов и выведения лингвистических портретов. При этом в текстах разных жанров встречаются схожие описательные паттерны, которые говорят о размытости границ между ними и позволяют рассматривать их в единстве.

Способы экзотизации, а также язык, с помощью которого создаются подобные оптики, отражают типичные представления общества об описываемой группе и представляют собой форму её антропологического познания. Именно этим и вызван мой интерес к языкам описания, которые использовали дореволюционные авторы текстов различных жанров о старообрядцах. Я предлагаю рассмотреть как эмоциональный контакт, представления о здравом смысле, а также идеологические воззрения авторов создают определённые рамки восприятия старообрядческой традиции. Иными словами, то, как пишут о староверах, говорит не только о самих староверах, но об авторах и их исследовательской оптике.

Я рассматриваю, на первый взгляд, мало примечательный пример старообрядческой общины Усинского края. Её история непродолжительна: в 1860-х годах из Центральной России и Западной Сибири группа старообрядцев переселяется на южную сторону Саян, на пограничную территорию, мало подконтрольную российской администрации. Спустя 20 лет в прессе появляются первые сведения об усинской общине. Староверов представляют искателями Беловодья, которые последовали за харизматичным лидером. Сама территория также получает неофициальное название Усинского края.

\footnotetext{
${ }^{1}$ Здесь речь идёт о символической власти, которой обладают определённые группы в силу особого доступа к публичному дискурсу (см.: ван Дейк, 2013: 32 и далее). В данном случае, речь идёт об авторитете, которым, безусловно, обладали учёные-этнографы. Например, о безграмотности «раскольников» высказывались и синодальные авторы, но данный аргумент приобретает дополнительный вес в профессиональной этнографической работе.

${ }^{2}$ Большинство крупных произведений, героями которых становились старообрядцы, опираются на подобный этнографический «элемент»: к ним относятся, к примеру, романы В. Я. Шишкова «Ватага» (1923), А. Т. Черкасова «Хмель» (1963), В. Афанасьева «Серафима и Бодан» (2017).
} 
В 1886 г. образуется Усинский пограничный округ - форпост русской колонизации Тувы (Татаринцева, Моллеров, 2016: 225). Рядом со старообрядцами появляется православная миссия. Часть первых поселенцев оказывается под влиянием белокриницкого согласия. Постепенно община принимает решение покинуть место. Последние публикации об усинских староверах выходят в печать в 1914 и 1915 годах. Но они опираются на материалы двадцати-сорокалетней давности. Вместе с уходом старообрядцев Усинский край теряет и свою «самобытность»: его больше не воспринимают как место с собственной идентичностью, да и административно он подчиняется соседним регионам.

\section{Материалы исследования}

В качестве источников я использую этнографические работы четырёх авторов: православного миссионера Н. А. Путилова (?-1902), минусинского купца, старообрядца белокриницкого согласия И. А. Пуговкина (1854-1931) и двух этнографов - А. В. Адрианова (1854-1920) и Ф. Я. Кона (1864-1941).

Первый оставил два обширных сочинения, в которых привёл физико-географические и экономические характеристики Усинского края, описание проживающего там коренного населения - тувинцев и русских поселений, большинство которых составляли староверы. О последних Н. А. Путилов рассказал достаточно подробно, выбрав центральной фигурой повествования личность их духовного лидера, Ивана Афанасьевича Липина, благодаря которому и состоялось переселение на Ус старообрядцев. Одно из сочинений под названием «Усинский край» опубликовано в нескольких номерах «Енисейских епархиальных ведомостей» за 1885 г. (Путилов, 1885abcdef). Второе - «Летопись Усинской миссии, находящейся на реке Усу, Енисейской губ., Минусинского округа, Шушенской волости, близ Китайской границы» (далее - «Летопись») - было издано посмертно ${ }^{1}$ стараниями иркутского историка и издателя «Сибирского архива» А. И. Линькова, опубликовавшего его на страницах своего журнала (№№ 1,2 , 3-4, 5, 6, 7-8, 9, 10, 12 за 1914 г. и №№ 1, 6, 7-8-9 и 10 за 1915 г.). При этом «Летопись» по большей части состоит из миссионерских отчётов и писем ${ }^{2}$ Путилова духовному начальству, в которых раз за разом приводит одну и ту же историю появления староверов на Усу и их текущей жизни. Поэтому несмотря на значительно больший объём, «Летопись» не даёт принципиально новых сведений по сравнению с «Усинским краем».

Очерк И. А. Пуговкина под названием «Усинские старообрядцы» вышел в № 210 за 1881 г. газеты «Русские ведомости», то есть, за 4 года до сочинения Путилова ${ }^{3}$. Сюжет и структура текста Путилова практически полностью совпадают с работой Пуговкина, за исключением некоторых деталей. Частично это объясняется тем, что оба автора опирались на одни и те же устные источники - рассказы местных жителей о переселении старообрядцев и первых годах их жизни на Усу. Однако вероятно и то, что Путилов был знаком с текстом Пуговкина.

Сочинение А. В. Адрианова «Раскольничьи общины в Сибири» об усинских староверах опубликовано в №№ 37 и 38 «Восточного обозрения» за 1882 г. (Адрианов, 1882ab). Небольшой по объёму текст ${ }^{4}$ в целом выстроен по той же схеме, что и очерки Пуговкина и Путилова. Центральным сюжетом своей работы Адрианов выбрал переселение староверов на Ус и первые годы жизни в Засаянье, а личность Ивана Афанасьевича - связующим звеном повествования. При этом рассказ Адрианова опирается на текст Пуговкина, а Путилова автор обвиняет в отрицательном влиянии на местное население (об этом см. ниже).

Работа Ф. Я. Кона «Усинский край» (Кон, 1914), в этом смысле выглядит более обстоятельной. Реконструируя историю старообрядческой общины на Усу, Кон часто цитирует своих собеседников. Кроме того, все устные сведения он подкрепляет выдержками из официальных, то есть, архивных источников. Вероятно поэтому в его изложении переселение староверов под предводительством И. А. Липина практически исчезает - местные архивы никаких данных на этот счёт, разумеется, не содержали, а одной устной историей Кон довольствоваться не хотел.

\footnotetext{
${ }^{1}$ Миссионер умер в 1902 году.

${ }^{2} \mathrm{~K}$ сожалению, мне не известно, сохранились ли оригиналы путиловских отчётов и писем, поэтому я не могу утверждать, что автор приводит их без редактуры. Однако в контексте настоящего исследования это не играет принципиальной роли.

${ }^{3}$ Пуговкин, И. А. (1881) Усинские старообрядцы (этнографический очерк) // Русские ведомости. № 210. С. 1-3.

${ }^{4}$ А. В. Адрианов больше известен своими «Очерками Минусинского края» (Адрианов, 1904).
} 
Таким образом, я рассматриваю этнографические описания разных уровней и направленности. Они основаны, прежде всего, на устных источниках - рассказах самих усинских староверов и их соседей. Однако каждый из авторов подходил к оценке достоверности сообщаемых ему сведений со своей позиции, которая была обусловлена социальным положением, идеологией (в данном случае, конфессиональной принадлежностью), представлениями об этнографическом нарративе. В одном случае автор (Путилов) намеренно показывал себя одним из активных участников событий повествования. В трёх остальных (Адрианов, Кон, Пуговкин) следует говорить о попытке с той или иной степенью успешности абстрагироваться от локального социума и «объективно» представить положение дел. Некоторые авторы (например, Кон) активно цитируют архивные документы - отчёты чиновников, донесения, статистические материалы.

\section{Критика источников}

Путилов всячески подчёркивал свою роль в деле борьбы с «расколом» и распространения официального православия в крае. Себя он описывал как защитника тувинцев, которых притесняли старообрядцы, и переселенцев-православных, которых сам же и пригласил на Ус. Себя он также выставлял жертвой постоянных нападок староверов. Однако едва ли реальное положение дел было настолько однозначным, как об этом сообщал Путилов. Даже современники миссионера обращали внимание на то, что тот занят поиском личной выгоды, играя на конфликтах между различными группами местного населения, и даже самостоятельно разжигая их (Адрианов, 1882b: 10; Кон, 1914: 38-40, 41-42).

Другой автор, Пуговкин, также не был случайным человеком на Усу. Будучи старовером, он видел себя адвокатом усинской общины, хотя большинство её составляли староверы-беспоповцы. При этом он явно был заинтересован в том, чтобы среди последних распространялась белокриницкая иерархия. Путилов пишет, что усинские белокриницкие «имеют сильную поддержку» в лице Пуговкина (Путилов, 1885f: 329), а приезжавшая на Ус делегация во главе с красноярским епископом Исаакием назвала его «дьячком» ${ }^{1}$.

Предвзятость Путилова и Пуговкина заставляет усомниться в достоверности приводимых ими сведениий. Тем не менее, нельзя сказать, что профессиональные этнографы были беспристрастны в своих оценках. Судя по тому, что Пуговкин высказывался в защиту Адрианова, их связывали доверительные отношения. Адрианов также высказывался довольно резко по отношению к Путилову, и в целом, ориентировался на созданный Пуговкиным нарратив. Факт посмертной публикации труда Путилова говорит о том, что и его материалам придавалось важное значение. Также Ф. Я. Кон приводит ряд выдержек из «Летописи» (Кон, 1914: 34, 36-37, 102-103).

На первый взгляд, работы Адрианова и Кона должны вызывать больше доверия, чем «любительские» Путилова и Пуговкина. Однако и к ним есть ряд вопросов. К примеру, Пуговкина можно считать своего рода миссионером от белокриницкой иерархии на Усу. В этом смысле он может считаться конкурентом Пуговкина. Адрианов, резко высказываясь в сторону Путилова, не только критиковал деятельность, но и выбирал сторону конфликта двух миссионеров. В этом отношении, Кон выглядит наиболее объективным из всех авторов. Однако здесь следует учитывать, что здесь и сама «объективность» является идеологически нагруженной. Выбирая в качестве объекта описания Усинский край, Кон следует политическим тенденциям, связанными с колонизацией Южной Сибири То есть, такая культурно-географическая единица как Усинский край существует, прежде всего, в глазах смотрящего. Кроме того, до Кона тот же ход совершал Путилов, пусть и в иных целях. И хотя работа последнего цитрируется, Кон использует только те сведения, которые посчитал достоверными.

\section{Теоретические подходы исследования}

В своём исследовании я прибегаю к понятию внутренней колонизации. А. М. Эткинд, благодаря которому данный термин стал популярным в современных российских исследованиях, рассматривает этос отечественной истории как страны, колонизирующей саму себя. В его определении внутренняя колонизация - это «процесс культурной экспансии, гегемонии, ассимиляции в пределах государственных границ, реальных или воображаемых» (Эткинд, 2013: 18). Данное понятие имеет и лите-

${ }^{1}$ Завохонец. Поездка на Ус преосвященного Исаакия // Сибирская газета. 1883, №16. С. 413-414. 
ратурное измерение, когда ассимилируемые народные массы экзотизируется и изображаются определенным образом. В этом смысле внутренняя колонизация сближается с воображаемым сообществом Б. Андерсона (Anderson, 1991), с той лишь разницей, что речь идёт не об изобретении нации, а о воображении «экзотического» сообщества. Особенно это касается маргинализованных религиозных групп, к которым относятся старообрядцы.

В западной научной традиции антропология складывалась как дисциплина, прилагаемая к исследованиям народов заокеанских колоний. Население метрополий, при этом изучалось посредством социологии (Соколовский, 2012: 130-131). Однако в странах Центральной и Восточной Европы применяется иной подход. Здесь возникает этнология как вариант антропологии, в фокусе которой находится культура «своего» народа (Гупта, Фергюссон, 2013; Gerholm, 2003: 159; Jasiewicz, Slattery, 2003: 187-189). К этой же традиции принадлежит и российская школа. То есть, если антропология - это инструмент производства колониального знания, то этнология - инструмент внутренней колонизации.

Выделяет российскую школу её глубокая связь с литературным процессом. Это ярко проявляется на примере интереса интеллектуалов к старообрядцам. Этнографические описания общин хотя и появляются, но носят, скорее, эпизодический характер. Все крупные работы являются историческими или историко-этнографическими. Такие авторы как, например, Щапов, по большей части пытаются разобраться в психологических и социальных процессах, которые привели к тому, что старообрядчество оказалось столько популярно в народе (Щапов, 1862). Другие же, как я уже упомянул, вынесли весь свой опыт работы со староверами в художественный текст. Сам Эткинд отмечает целый пласт влияния на русскую литературу (Эткинд, 1998). Однако литература - это ещё и приём воображения народной массы.

Реальная дистанция, как культурная, так и географическая, между теми, кто пишет, и теми, о ком пишут, не обязательно должна быть очень большой. Экзотизация, как один из способов внутренней колонизации, оказывается настолько вписанной в оптику этнографического описания, что само действие описания оказывается экзотизацией. Не случайно в этой статье я обращаюсь к столь разным авторам. Кон и Адрианов, безусловно, принадлежат интеллектуальной элите, о которой пишет Эткинд. Купец и старовер Пуговкин, мещанин, а затем священник-миссионер Путилов к ней вряд ли относятся, а их имена сохранились, в основном, только в связи с локальной усинской историей. Однако оптики этнографического описания в их текстах во многом совпадают. Именно поэтому важно рассматривать их вместе, независимо от социального и академического статуса авторов. Важным представляется здесь изображение себя как чужого, характерное для русского романтизма (Эткинд, 2013: 90-91), а также неявная политизации раскола (там же: 308-311), когда старообрядцам приписывается либо прогосударственная (когда они выступают в роли колонистов - проводников интересов России), либо антигосударственная роли (т. к. раскол приводит к духовной распущенности).

Нужно также учитывать, что старообрядцы были вынуждены действовать в рамках религиозного поля, главным игроком которого выступала официальная православная церковь. Бурдье, когда рассуждает о формировании религиозного поля, говорит о способности религии к различению собственно религии и религиозной профанации (куда относятся все стоящие низко по социальной шкале современные верования), а также о вкладе религии в поддержание существующих властных структур (cм.: Bourdieu, 1991: 12, 31-38). Это не могло не влиять на оптику этнографических исследований старообрядцев.

Для того, чтобы отделить религиозные зёрна от плевел, церковь должна разбираться в том, во что верят, и что практикуют профаны. В этом смысле описание ересей - это также этнография (cм.: Berzon, 2016: 27-57). Классификация ересей занимает в такой религиозной этнографии важное место: она не только позволяла «описать» особенности сообщества, но и определить её место на шкале вреда. Таким образом классификация превращалась в инструмент осуществления власти. Не случайно среди старообрядческих групп власть особое внимание уделяла т. н. «особо вредным сектам», к которым причисляли, например, странников (Андерсон, 1908: 181-182). Все эти особенности сохраняются и в этнографических описаниях светских авторов.

\section{«Отченька» Иван Афанасьевич: о роли личности в этнографических описаниях}

До становления антропологии религии как самостоятельной дисциплины общим местом в описаниях религиозных групп, отличающихся от мейнстрима, было подчёркивание роли её основателя, «ересиарха». Такой приём должен был представить убеждения членов этой группы как ложные, а 
саму веру как заблуждение, ведь будучи продуктом творчества лишь одного человека, она не могла соответствовать идее трансцендентального, вечного Бога. Этот же принцип прослеживается и в этнографических описаниях усинских старообрядцев: история их переселения и первых лет жизни за Саянами раскрывается через личность и характер их духовного лидера, Ивана Афанасьевича Липина. В том, как о нём пишут Путилов, Пуговкин и Адрианов, очень много карикатурного: с одной стороны, Липин - это бывший разбойник, преуспевший на лоне духовной деятельности, заставивший несколько сот человек беспрекословно себе подчиняться, а с другой, он ленив и жаден, что, в итоге, приводит его к краху. Очевидно, что все три автора очень предвзято излагают биографию лидера усинских староверов. Но значение деятельности Липина настолько важно для нарратива, что даже Кон, который попытался более «беспристрастно» оценить его, был вынужден как-то прокомментировать предоставленные предшественниками факты.

И. А. Липин приводит за собой первую группу поселенцев на Ус в начале $1860-$ г гг. (Путилов, 1885а: 8). Однако его биография начинается за 20 лет до этого события. Особенно важный момент - начало духовного лидерства Липина. Его считают беглым солдатом, который какое-то время занимался разбоем, и лишь впоследствии назвался старообрядцем ${ }^{1}$ (Адрианов, 1882а: 12; Путилов, 1885а: 8-9). Например, такую точку зрения предлагает уже старовер Пуговкин, тем самым исключая Липина из числа «своих», «настоящих» старообрядцев:

«От одного из своих товарищей ${ }^{2}$ научился он ${ }^{3}$ первым правилам старообрядчества - слагать пальцы для крестного знамения и класть “начал” и под видом монаха бежавшего якобы из иргизского старообрядческого монастыря во время его “раззорения начальством”, - так всегда выражаются старообрядцы - поселился в одном старообрядческом селении Николаевского уезда, Самарской губернии. С домохозяином своим он сразу поладил, от него усвоил все уставы старообрядчества - какое количество полагается поклонов или кафизм по псалтыри вместро церковной службы и т. п.»4.

Разные авторы подчёркивали, что учение Липина было довольно жестоким и включало убийство «еретиков» (т. е. православных), которое оправдывалось тем, что таким образом душа убитого очищается и попадает в рай. Воровство у православных также не считалось грехом (Путилов, 1885b: 73). По распоряжению Ивана Афанасьевича его приближённые убивали тех, кто осмеливался оспаривать его власть или авторитет (там же: 73-74). Другая его черта - это увлечение женщинами. Хотя Липин называл себя священноиноком, у него было две жены, а также он завёл для себя нечто вроде «права

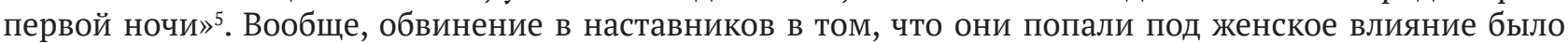
частым мотивом во внутриобщинной полемике и даже могло приводить к расколам (Paert, 2003: 79, Rogers, 2009: 84). В этом контексте весьма характерно замечание Пуговкина о том, что Липин надел на себя именно женскую мантию, объявив себя священноиноком ${ }^{6}$

Биография Липина в изложении разных авторов строится по одной и той же схеме, различаются лишь некоторые несущественные детали․ Тем не менее, очевидно, что каждая версия была написана с разными целями. Так, Пуговкин, скорее, стремился представить белокриницкое согласие в лучшем свете, а Путилову требовалось показать, с какими трудностями и опасностями ему как миссионеру приходится сталкиваться ${ }^{8}$.

В отличие от остальных авторов, Ф. Я. Кон попытался каким-то образом объяснить эти черты усинского лидера. Во-первых, он постарался некоторые устные сведения подкрепить официальными документами. Например, это касается обвинений Липина в совершении убийств (Кон, 1914: 33-35). Вовторых, Кон прибегает к эволюционистской логике, характерной для дореволюционной этнографии,

\footnotetext{
${ }^{1}$ Пуговкин И. А. Усинские старообрядцы (этнографический очерк) // Русские ведомости. 1881, № 210. С. 1.

${ }^{2}$ По разбойничьей «шайке».

${ }^{3}$ Иван Афанасьевич Липин. Пуговкин и прочие авторы считают, что в это время его звали просто Фомой.

${ }^{4}$ Пуговкин И. А. Усинские старообрядцы (этнографический очерк) // Русские ведомости. 1881, № 210. С. 1.

${ }^{5}$ Там же. С. 2.

${ }^{6}$ Там же.

${ }^{7}$ Например, Путилов и Кон пишут, что Липина называли «батюшкой», поэтому и согласие его «батюшкино». Пуговкин и Адрианов отмечают, что к Липину обращались не иначе как «отченька». Скорее всего, в воспоминаниях усинцев фигурировало несколько вариантов обращения к Липину, что и зафиксировали разные авторы.

${ }^{8}$ Тут ещё раз подчеркну, что статья Путилова появляется после того, как Пуговкин и Адрианов открыто написали о его отрицательной роли в жизни усинцев. Т. е. ему необходимо было восстановить свою репутацию.
} 
объясняя поступки Ивана Афанасьевича и его последователей. В частности, Кон пишет, что убийства, которые совершались по его - то есть Липина - распоряжению следует рассматривать как «смертные приговоры патриарха и главы общины, не признанного законом, но вполне признаваемого и почитаемого членами общины» (там же: 34).

Эволюционизм Кона заключается в данном примере в отнесении поселений старообрядцев на Усу к определённому «общественному типу». Оказавшись в месте, которое слабо контролировалось государством, община начинает жить по «патриархальным законам», как называет это Кон ${ }^{1}$. Такая характеристика представляет собой пример экзотизации сообщества. Несмотря на отсутствие качественной инфраструктуры или видимого присутствия власти, усинская община вряд ли за несколько лет стала жить только по собственным, внутренним законам. Впрочем, такое предположение не удивительно для интеллектуала. Например, по утверждению Эткинда, народники видели в социальной структуре русских сектантов «наследие первобытного социализма» (Эткинд, 2013: 322).

\section{Конструирование культурного ландиафта}

Параллельно с созданием определённого образа усинской общины, происходило и конструирование места, в котором она жила. Само понятие Усинского края появляется постепенно, когда интерес к этой территории возрастает. В очерке Пуговкина речь ещё идёт только о старообрядческой общине, тогда как территорию он называет «отдалённым уголком» Минусинского округа, около китайской границы ${ }^{2}$. Миссионер Путилов называет свой очерк «Усинским краем», смещая акцент тем самым со старообрядческой общины на образ территории. Он делает это совершенно сознательно, поскольку тем самым повторяется структура сочинений профессиональных этнографов, которые всегда приводят физико-географические и экономические характеристики региона проживания описываемого сообщества ${ }^{3}$. Этот подход создаёт впечатление систематичности: так, Путилов формально говорит не только о старообрядцах, а ещё и о тувинцах, православных, рабочих приисков и т. д. Впрочем, о них он пишет в разы меньше и лишь в контексте взаимоотношений со староверами ${ }^{4}$. Таким путём именно старообрядческая община становится основным предметом репрезентации региона.

В этом смысле «Усинский край» Кона завершает процесс конструирования образа региона. В этом очерке подробно рассказывается о географии, инфраструктуре, истории, экономике и административном значении края. Описание старообрядческой общины представлено уже в контексте общего нарратива, хотя оно по-прежнему призвано сделать регион особенным. При этом в работах других этнографов акцент ставится на автохтонном населении - тувинцах. В качестве примера можно привести очерк В. А. Ошуркова, опубликованного в одном из томов «Сибирского сборника» (Ошурков, 1893). Своё сочинение Ошурков называет поэтично «Из странствований по земле Урянхов». Автор создал его на основе материалов разведывательной экспедиции территорий на границе с Китаем. Как и Кон, Ошурков использует термин «Усинский край», однако о русском населении пишет мало (там же: 73).

Вслед за Путиловым, Кон отмечает, что первые переселенцы-староверы отправились на Ус в поисках Беловодья (Кон, 1914: 29). Легенда о Беловодье была весьма популярна среди «образованной публики» Российской Империи, поэтому факт того, что усинцы активно занимались его поисками ${ }^{5}$ был призван придать «изюминки» этнографическому сочинению: читателю сразу становилось ясно, что речь идёт не про «обычных раскольников». В этом смысле Усинский край некоторое время составлял

\footnotetext{
${ }^{1}$ При этом он следует языку цитируемых официальных документов: «[О]бразовалось коренное Усинское население, отрезанное от православного населения Минусинского округа всею толщею Саянского хребта, зажившее своей раскольничьей патриархальной жизнью. Ив. Аф. остался главным руководителем и настоятелем всего населения, разыгрывая роль патриарха и чиня суд и расправу», - приводит Кон характеристику усинских староверов из архива Усинского пограничного управления (Кон, 1914: 33).

${ }^{2}$ Пуговкин И. А. Усинские старообрядцы (этнографический очерк) // Русские ведомости. 1881, № 210. С. 1.

${ }^{3}$ Впрочем, эта часть сочинения Путилова вышла довольно короткой - всего 3 страницы (Путилов, 1885d).

${ }^{4} \mathrm{~B}$ «Летописи» Путилов также неоднократно сообщает о попытках вести миссионерскую деятельность среди тувинцев и учить тувинский язык, однако они не были успешными, поскольку даже в собственных отчётах он не мог написать, что кто-то действительно бы принял крещение.

${ }^{5}$ Путилов сообщает о трёх попытках староверов отыскать Беловодье уже после после основания усинских поселений. Поисковые партии уходили в Туву, Бийский округ и Монголию, но успеха не добились (Путилов, 1885c: 164-165).
} 
конкуренцию своему более знаменитому «собрату» на Алтае - Бухтарминскому краю, который более прочно ассоциируется с названной легендарной страной. В результате создавался романтический образ региона и старообрядцев, тщетно ищущих осколки старой, благочестивой жизни:

«Попавши в Бухтарминский край, вы невольно переноситесь в седую старину Руси Московской, когда русские славяне в основу жизни своей полагали религиозное начало, когда религия была смыслом и целью жизни. <..> В поисках потаённых мест для насаждения религиозного благочестия, русские раскольники в виде калик перехожих, горбунчиков и звероловов появились в предгорьях Алтая <...> [С]реди крепостных шахтёров уже ходила легенда о каком-то таинственном “Беловодье”, которые существует будто бы, где-то по близости тотчас за “Камнем” ${ }^{1}$ и которое нашли русские пустынножители - староверы» (Гребенщиков, 1914: 5-7).

Помимо романтизации культурного ландшафта, легенда о Беловодье давала повод связывать усинских староверов с согласием бегунов. Такая точка зрения сохранялась долгое время среди исследователей. Например, К. В. Чистов отмечал, что «распространение легенды о Беловодье было связано со специфической конспиративной деятельностью чрезвычайно своеобразной крестьянской анархистской религиозно-общественной организации - сектой “бегунов” или “странников” (Чистов, 2003: 280).

Ниже я оспариваю факт принадлежности усинцев данному согласию. Но для дореволюционных авторов он был очевиден, и это только усиливало романтический ореол вокруг жителей Усинского края: бегуны привлекали интеллектуалов своей таинственностью².

\section{Конфессиональная идентичность}

В этнографии старообрядческих сообществ важное место занимает определение их конфессиональной принадлежности. В Сибири, особенно среди переселенческих групп, к которым принадлежали усинцы, идентификация зачастую осложнена тем, что локальные особенности не позволяют однозначно отнести общину к тому или иному известному течению. Сами старообрядцы также могут затрудняться с самоопределением, поскольку в ходу распространены либо очень специфические термины (усинцы, скорее, относятся к этой категории), либо, напротив, слишком общие (например, «християне» - типичное самоназвание современных часовенных старообрядцев Сибири).

Можно выделить два основных подхода к решению этой проблемы. Один из них опирается на методику археографических исследований, когда локальную группу относят к какому-либо известному согласию старообрядцев. Как правило, это достаточно крупные течения, создававшие свою полемическую литературу, в которой разрабатывались правила жизни и исполнения обрядов, характерные именно для них. Либо это мелкие сообщества, известные по историческим документам. Основной его недостаток заключается в том, что соотнести этнографические данные с письменными правилами не всегда представляется возможным. В ранних этнографических записях зачастую отсутствуют необходимые для такого соотнесения детали, да и сами этнографы не всегда могли однозначно определить конфессиональную принадлежность группы (Рыговский, 2019с). Локальные особенности самоидентификации и религиозных практик также не всегда находят подтверждение в полемической литературе старообрядцев ${ }^{3}$.

Другой подход заключается в «вернакуляризации» согласия. В таком случае локальная группа признаётся отдельным согласием даже в отсутствие собственной литературы или лидеров, которые бы это провозглашали. Так, уймонских часовенных (Алтай) выделяют в согласие «оймонов» (Королёва, 2012: 319), а горно-алтайских определяют как «стариковских», противоставляя их прочим часовенным (Шитова, 2012). При этом недостаток сведений о связях локальной группы со старообрядцами других регионов не позволяет соотнести её с каким-либо крупным сообществом. Кроме того, это осложняется постоянными спорами, которые происходят между различными территориальными сообществами одного согласия. Последнее довольно типично для часовенных, чьи религиозные практики и понятия могут различаться от общины к общине из-за отсутствия централизованного управления. В результате внутри согласия велась постоянная полемика по разным вопросам, но к новым разделениям она не приводила (Зольникова, 2016: 159-160; 2018: 155; Рыговский, 2019а: 64-66). Аналогичные процессы

\footnotetext{
${ }^{1}$ Местное название Алтайский гор.

${ }^{2}$ См.: Эткинд, 2013: 316.

${ }^{3}$ Например, филипповцы Кемеровской области (Казанцева, 2014: 24-32).
} 
проходили и в других сообществах, например, у поморцев Верхокамья, которые, впрочем, разделились на максимовских и дёминских (Rogers, 2009: 71-103).

Оба подхода выявляются в этнографических описаниях усинских староверов. Н. А. Путилов и Ф. Я. Кон полагали, что они принадлежат странническому согласию (Кон, 1914: 101-104; Путилов, 1885a: 9). В изложении Пуговкина и Адрианова существует лишь учение Ивана Афанасьевича Липина и его последователи. Адрианов вскользь упоминает, что проповедь усинцев привлекла в их ряды местную «стариковщину ${ }^{1}$, однако он не уточняет, что первые сами к ней относились. При этом Путилов и Кон сообщают, что после смерти Ивана Афанасьевича его паства распадается на два согласия «батюшкино» и «фёдорово». Первые продолжают придерживаться учения своего лидера, вторые от него отказываются (и называются по имени нового вожака) (Кон, 1914: 35-38; Путилов, 1885f: 328). То есть, усинские староверы уже перестают быть просто странниками, происходит «вернакуляризация» их конфессиональной идентичности. Пуговкину же о подобном расколе ничего не известно. Он отмечает, что после проповеди минусинских «австрийцев» ${ }^{2}$ большинство усинцев присоединяется к поповцам, и лишь малая часть следует установкам преемника Липина, по имени которого Пуговкин называет их «лазаревщиной» ${ }^{3}$. Адрианов же указывает, что после Ивана Липина появляются «чашники» и «австрийцы» (Адрианов, 1882b: 10).

Далее я разберу аргументы Путилова и Кона о причислении усинских староверов к странникам. Кон находит совпадения с основами учения странников: побег от мира, новое крещение с переменой имени, уничтожение паспортов. Тот факт, что по прибытии на Ус переселенцы взяли новые имена, Кон считает свидетельством принятия повторного крещения. Этнограф также полагает, что «странники считали себя иноками и почитали добродетелью покровительство всем бездомным» (Кон, 1914: 104). Все авторы действительно сообщают о том, что усинские староверы изменяли свои имена. Путилов пишет, что это произошло непосредственно на Усу (Путилов, 1885a: 11), а Пуговкин - что ещё в Тобольской губернии ${ }^{4}$. Однако почему это свидетельствует о факте крещения, а не о попытке скрыться от возможного преследования властей ни Кон, ни Путилов не поясняют.

От всех прочих согласий странников отличает специфическая структура сообщества. Оно делится на две половины - собственно странников, которые и должны совершать крещение перед уходом в мир, и странноприимцев. Последние должны содержать странников у себя в домах, однако они не являются полноценными членами согласия, поскольку над ними ещё не совершено крещение и странникам запрещено питаться с ними за одним столом. А. И. Мальцев пишет, что такое разделение было серьёзным вызовом для согласия, поскольку от странноприимцев зависело обеспечение странников, но они считались живущими «в миру» (Мальцев, 1996: 184-224). Несмотря на это противоречие, практика крещения во взрослом состоянии перед уходом из мира сохранялась в локальных сообществах. Над младенцами совершалось лишь оглашение (Боровик, 2003: 268). Поэтому по её наличию можно было бы судить о конфессиональной принадлежности усинцев.

Путилов, как и вслед за ним Кон, сообщают о существовавшем разделении на странников и странноприимцев. Тем не менее, создаётся впечатление, что под этими терминами они имели в виду нечто иное. Путилов пишет, что на Усу «два родных брата или отец с сыном носили разные фамилии, от того, что один был монастырский, а другой носил настоящую фамилию» (Путилов, 1885a: 12). Можно было бы подумать, что первый - это странник, а второй, с настоящей фамилией, странноприимец. Однако Путилов тут же продолжает, что они оба «были, так называемые, странноприимцы; настоящие же странники жили особняком в горах, в отдельных избушках. Странноприимцы доставляли им всё, что нужно для жизни» (там же). Далее Путилов замечает, что к «монастырским» относятся, прежде всего, пришедшие с Иваном Афанасьевичем Липиным староверы (47 семей) 5 . Вероятно такое прозвище

\footnotetext{
${ }^{1}$ Так в Сибири было принято называть часовенное согласие.

${ }^{2}$ Староверов белокриницкого согласия, которое оформляется в 1846 г. после присоединения к староверам епископа Амвросия и образования первой полноценной старообрядческой иерархии. Имя «австрийцев» согласие получило по той причине, что переход Амвросия в старообрядчество осуществился на тогдашней территории Австро-Венгерской империи в селе Белая Криница (альтернативное название согласия - «белокриницкие», «белокриницкая иерархия»). В настоящее время данное село принадлежит Украине.

${ }^{3}$ Кон пишет лишь о 3-х семействах белокриницких на Усу, против 100 семей беспоповцев (Кон, 1914: 38). Не стоит забывать, что, будучи представителем белокриницких, Пуговкин сам был причастен к их присоединению.

${ }^{4}$ Пуговкин И. А. Усинские старообрядцы (этнографический очерк) // Русские ведомости. 1881, № 210. С. 1.

${ }^{5}$ Судя по предыдущему замечанию, к «монастырским» относились не все они, а те, кто переменил фамилии.
} 
связано с тем, что для иркутского начальства первые переселенцы представились бежавшими жителями Иргизских монастырей, о чём я уже писал выше. Позднее на Ус переселяются 64 семейства из Западной Сибири и 25 из Минусинского округа (Путилов, 1885e: 289). То есть, перемена фамилии и крещение, если оно вообще имело место, не означали уход от мира, как это принято у странников. Последними Путилов называет отшельников. Это больше напоминает привычную для енисейских часовенных картину, когда возле деревни поселяются монахи или строится монастырь, который мирские старообрядцы и обеспечивают (Татаринцева, Моллеров, 2016: 200; Татаринцева, Стороженко, 2015: 112).

Ещё одно серьёзное возражение против отнесения усинских староверов к странникам является наличие таинства причастия, сообщаемый самим же Путиловым. Беспоповские согласия не имели причастия, за исключением часовенных, которые либо используют т. н. «богоявленскую воду» (Зольникова, 2001; Рыговский, 2019b; Черных, 2007), либо «запасное причастие», судя по всему, бывшее в ходу на Усу:

«Беспоповцы «батюшкина согласия» причащаются запасными дарами, которые имеют такое происхождение. В первые времена появления раскола какой-то старец Авраамий вынес, будто бы, из Соловецкого монастыря Святые Дары. Но так как этих Даров не достаточно было бы для всех ревнителей древлего благочестия, то завели тесто, вложили в него Св. Дары и приготовили хлебы. От этих хлебов оставлялась некоторая часть для нового затвора и т. д. Часть таких даров принесеня была и на Ус» (Путилов, 1885f: 329);

«Причастие устинским старообрядцам в достаточном количестве наготовлено ещё их бывшим “отченькой”, Иваном Афанасьевым. Тот приготовлял его таким образом: в кислое пшеничное тесто примешивал несколько крошек сухарных, которые он называл “запасным агнцем”, доставшимся ему, якобы, от благочестивых иргизских старообрядческих священников; из этого теста пек большие круглые хлебы, без всякого тиснения; искрошив их, затем, на-мелко - раздавал крошки своим наставникам для причащения верных. Причастие это называлось также “запасным агнцем”»1.

Причастие осталось у часовенных как следствие их беглопоповского прошлого. Признавая возможность принимать священников от православной церкви, часовенные считали «видимое причастие» необходимым для спасения таинством. Поэтому не случайно Пуговкин пишет, что усинцы пользовались «запасным агнцем», полученным от священников на Иргизе. В то же время Путилов отмечает о том, что у части усинцев такой практики не было, и они спасались «через “веру всеусердну и делание огнеопально” (Путилов, 1885f: 329), что уже характерно для большинства беспоповских согласий. Такого убеждения Путилов приписывает «фёдорову» согласию, которое появилось после смерти Липина в 1876 году. Миссионер полагал, что оно образовалось в результате протеста части усинцев против безграничного деспотизма Ивана Афанасьевича (там же: 328-329). Эта ситуация напоминает существовавший во многих территориальных сообществах часовенных раскол, связанный с представлениями о природе Антихриста. Одни считали, что Антихрист должен явиться в «чувственном виде», т. е. будет конкретным человеком. Другие же, что он уже воцарился в виде духа, и поэтому таинство евхаристии более невозможно. Такое разделение известно сейчас в Горной Шории (Литвина, 2016; Рыговский, 2019а: 67-71), а в прошлом существовало в Туве (Зольникова, 2016) и в целом охватывало часовенное согласие (Покровский, Зольникова, 2002: 226-238).

При этом усинские часовенные освящали и «богоявленскую воду»:

«На ногах моление совершалось им один раз в год², 5-го января ${ }^{3}$, на вечерне, во время водосвятия. Наполнялась водою кадка, увешанная цветными платками с четырёх сторон; прилеплялись к ней свечи, зажигавшиеся при начале вечерни. По прочтении Евангелия, “отченька” трижды осенял воду крестом и пел стих: “Приидите на воду живу, священник кропит водою, освящает и просвещает”. По исполнении этого стиха все присутствующие черпали и пили освящённую таким образом воду; воде этой приписывалось даже и целебное свойство» ${ }^{4}$

${ }^{1}$ Пуговкин И. А. Усинские старообрядцы (этнографический очерк) // Русские ведомости. 1881, № 210. С. 3.

${ }^{2}$ Имеется в виду Липин, который по утверждению Пуговкина, лично вёл лишь одно богослужение в году, а все остальные проводил лёжа.

${ }^{3}$ Богоявление или Крещение Господне по старому стилю отмечалось 6 января (по-новому - 19 января), а 5 января начиналась вечерняя служба, посвящённая этому празднику. В этот же вечер происходило и водосвятие. ${ }^{4}$ Пуговкин И. А. Усинские старообрядцы (этнографический очерк) // Русские ведомости. 1881, № 210. С. 2. 
Приводимые Пуговкиным сведения о том, как освещалась и употреблялась эта вода совпадают с современными практиками староверов часовенного согласие. Её использование в качестве причастия широко распространено среди часовенных Енисея (т. е. Тувы и Красноярского края) (Рыговский, 2019b: 24-25). Аналогичная практика характерна и для часовенных других регионов, например, Пермского Прикамья (Черных, 2007). Это лишний раз свидетельствует в пользу идентификации усинских староверов как часовенных.

К какому же согласию относились усинские староверы? Вполне вероятно, что Путилов неверно идентифицировал их как странников, поскольку те переселялись «на Беловодье». В XIX веке распространение легенды о Беловодье ошибочно приписывалась этому согласию, однако она, скорее, была связана именно с часовенными. Тем не менее, нельзя утверждать, что это были именно часовенные в силу того, что практики локальных общин могут отличаться от правил, предписанных полемической литературой согласия. Ю. В. Боровик отмечает, что во второй половине XIX века наблюдается активный переход часовенных к странникам. Например, один из авторитетных начётчиков в Пермском уезде В.И. Рукавицин начинает сомневаться в некоторых постулатах часовенных и сближается со странниками (Боровик, 2003: 263). Вполне возможно, что духовный лидер усинцев сочетал элементы разных учений. Такие согласия «на стыке» известны в этнографической литературе. Например, на Алтае практически одновременно с появлением староверов на Усу появилось согласие «православных христиан», которые в обрядовом отношении напоминали часовенных, но придерживались некоторых убеждений поморцев. При этом «православные христиане» активно критиковали и тех и других (Чудновский, 1890: 60-74). Однако гораздо важнее то, что практики усинцев больше напоминали часовенных, что, вероятно, объясняет, куда впоследствии «исчезли» странники: они легко могли влиться в растущее сообщество часовенных, активно переселявшихся в это время в Туву и на Большой Енисей.

Тем не менее, этнографические описания не позволяют сделать однозначные выводы о конфессиональной принадлежности усинцев. Поскольку большинство авторов интересовалось «нравственной составляющей» обрядовой жизни усинских староверов, т. е. насколько она соответствуют православной догматике, на противоречия в повествовании между предписываемым учением и реальными практиками они не обращали внимание.

\section{Заключение}

Анализ описаний усинской старообрядческой общины позволяет сделать некоторые выводы о том, как был устроен дореволюционный этнографический нарратив о религиозных сообществах. Прежде всего, он базируется на экзотизации конфессиональных особенностей описываемой группы. Представляя переселенцев на Ус представителями согласия странников, искавших легендарную страну Беловодье, авторы отсылают к паттернам, легко узнаваемым читателями конца XIX - начала XX века. С одной стороны, это выглядело как осколок старины, дошедшей до современников. Но по большей части, такие «верования» как бы намекали на то, что русская община без контроля и государственного управления легко поддаётся вредному влиянию.

Не случайно в такой этнографии на первый план выходят именно непривычные для большинства православных практики. Такие как, например, освящение воды без участия духовенства или перемена имён. Они лишний раз дискредитировали старообрядческое мировоззрение. При этом об их происхождении практически ничего не сообщается.

Весьма характерно, что помимо конструирования общины старообрядцев, происходит и конструирование региона, в котором они проживают. В некотором смысле, «выявление» региона, обозначение его границ и условий проживания и экономического потенциала даже важнее, чем этнографическое описание религиозной общины. В случае с Усинским краем это усиливается из-за изменение его стратегического положения на границе с Тувой. Старообрядцы в этом смысле становятся как бы первыми, вероятно, невольными проводниками государственных интересов. И в этом и заключается парадокс внутренней колонизации. Староверы - те, кого колонизируют. Для образованной публики они ещё большие чужаки, чем большинство народа, тем более что для последнего они создают постоянную угрозу распространения вредных идей. Однако они же оказываются и колонизаторами, поскольку с их помощью распространяются хозяйственные и экономические практики, характерные для остальной России. А вслед за староверами приходит и государство, с которым несмотря на сопротивление, они не могут полностью разорвать связи. 


\section{СПИСОК ЛИТЕРАТУРЫ}

Адрианов, А. В. (1882а) Раскольничьи общины в Сибири // Восточное обозрение. № 37. С. 11-15.

Адрианов, А. В. (1882b) Раскольничьи общины в Сибири // Восточное обозрение. № 38. С. 9-12.

Адрианов, А. В. (1904) Очерки Минусинского края. Томск: Паровая типо-литография П. И. Макушина. 61 с.

Андерсон, В. М. (1908) Старообрядчество и сектанство: исторический очерк русского религиозного разномыслия. СПб. : Типография Первой трудовой артели. 460 с.

Боровик, Ю. В. (2003) «Камень претыкания» и «противогосударственный раскол» (о странниках Пермской губернии в начале XX в.) // Уральский сборник. История. Культура. Религия. Вып. 5. / отв. ред. И. В. Починская. Екатеринбург : Уральский университет. 344 с. С. 261-272.

ван Дейк, Т. А. (2013) Дискурс и власть: Репрезентация доминирования в языке и коммуникации / пер. с англ. М. : Книжный дом «ЛИБРОКОМ». 344 с.

Гребенщиков, Г. Д. (1914) Алтайская Русь: историко-этнографический очерк // Алтайский альманах / ред. Г. Д. Гребенщиков. СПб. : Жизнь Алтая. 202 с. С. 1-37.

Гупта, А., Фергюссон, Дж. (2013) Дисциплина и практика: «поле» как место, метод и локальность в антропологии // Этнографическое обозрение. № 6. С. 3-44.

Гурьянова, Н. С. (1988) Крестьянский антимонархический протест в старообрядческой эсхатологической литературе периода позднего феодализма. Новосибирск : Наука. 182 с.

Зольникова, Н. Д. (2016) Дневник археографической группы Н. Н. Покровского 1967 г. // Урало-Сибирский патерик: тексты и комментарии : в 3 т. / отв. ред. Н. Н. Покровский. М. : Издательский Дом ЯСК. Кн. 2 (Т. 3). 295 с. С. $153-193$.

Зольникова, Н. Д. (2018) Полевой дневник археографической группы Н. Н. Покровского (Тува, 6-7 августа 1967 г.) // Известия Иркутского государственного университета. Т. 23. С. 152-157.

Зольникова, Н. Д. (2001) Скитские письма второй половины XX века (Нижний Енисей) // Общественное сознание и литература XVI-XX вв. / отв. ред. Н. Н. Покровский. Новосибирск : Изд-во СО РАН. 381 с. С. $292-325$.

Казанцева, Т. Г. (2014) «Монастырь Данилов, филипповский толк»: особенности догматики староверов югозападных районов Кузбасса // Духовные стихи в рукописных сборниках старообрядцев филипповского согласия (по материалам Кемеровского территориального собрания ГПНТБ СО РАН) / ред. А. Ю. Бородихин и др. Новосибирск : ГПНТБ СО РАН. 363 с. С. 9-62.

Керов, В. В. (2010) Предпринимательство старообрядцев в России // Частное предпринимательство в дореволюционной России: этноконфессиональная структура и региональное развитие, XIX - начало XX в. / отв. ред.: Б. В. Ананьич и др. М. : РОССПЭН. 549 с. С. 31-111.

Керов, В. В. (2016) “Се человек и дело его...”: Конфессионально-этические факторы старообрядческого предпринимательства. М. : Экон-Информ. 590 с.

Кон, Ф. Я. (1914) Усинский край / Записки Красноярского подотдела Восточно-Сибирского отдела Императорского русского географического общества. Записки по географии. Т. 2. Вып. 1. Красноярск : Типография б. М. И. Абалакова. 117 с.

Королёва, Е. В. (2012) Этническая самоидентификация Оймонских старожилов по материалам автобиографических воспоминаний У. М. Аргоковой и С. И. Солонкиной // Актуальные проблемы исторических исследований: взгляд молодых ученых : сборник материалов II Всероссийской молодежной научной конференции / отв. ред. Р. Е. Романов. Новосибирск: Нонпарель. 336 с. С. 318-324.

Литвина, Н. В. (2016) Религиозное соседство шорцев, челканцев и старообрядцев: стереотипы и взаимодействие // Сибирские исторические исследования. № 1. С. 59-73.

Мальцев, А. И. (1996) Староверы-странники в XVIII - первой половине XIX в. Новосибирск : Сибирский хронограф. 266 с.

Ошурков, В. А. (1893) Из странствований по земле Урянхов // Сибирский сборник. Вып. 2. С. 73-132.

Покровский, Н. Н., Зольникова, Н. Д. (2002) Староверы-часовенные на востоке России в XVIII-XX вв. M. : Памятники исторической мысли. 471 с.

Путилов, Н. А. (1885a) Усинский край // Енисейские епархиальные ведомости. № 1. С. 7-12.

Путилов, Н. А. (1885b) Усинский край // Енисейские епархиальные ведомости. № 5. С. 72-76.

Путилов, Н. А. (1885c) Усинский край // Енисейские епархиальные ведомости. № 9. С. 163-169.

Путилов, Н. А. (1885d) Усинский край // Енисейские епархиальные ведомости. № 12. С. 217-219.

Путилов, Н. А. (1885е) Усинский край // Енисейские епархиальные ведомости. № 16. С. 289-294.

Путилов, Н. А. (1885f) Усинский край // Енисейские епархиальные ведомости. № 19-20. С. 328-332.

Расков, Д. Е. (2012) Экономические институты старообрядчества. СПб. : СПбГУ. 343 с. 
Рыговский, Д. С. (2019а) Енисейские и шорские староверы: сложная структура «простого» сообщества // Новые исследования Тувы. № 1. C. 60-74. DOI: https://doi.org/10.25178/nit.2019.1.5

Рыговский, Д. С. (2019b) Влияние религиозных практик на социальную структуру енисейских староверов // Антропологический форум. № 41. C. 11-35. DOI: https://doi.org/10.31250/1815-8870-2019-15-41-11-35

Рыговский, Д. С. (2019с) Механизмы различения в среде сибирских староверов // Язык, книга и традиционная культура позднего Русского средневековья в науке, музейной и библиотечной работе: труды IV Международной научной конференции / сост. Ю. С. Белянкин, Е. В. Воронцова, Н. В. Литвина М. : Изд-во Московского университета. 780 с. С. $728-737$.

Соколовский, С. В. (2012) Социология vs. антропология: запоздалые заметки на полях к дискуссии «физики vs. лирики» // Антропологический форум. №16. С. 130-139.

Татаринцева, М. П., Моллеров, Н. М. (2016) Русские в Туве (конец XIX - начало XX в.): История. Этнография. Культура. Новосибирск : Наука. 295 с.

Татаринцева, М. П., Стороженко, А. А. (2015) Старообрядцы Тувы: ретроспектива и современность. Saarbrucken: Lambert Academic Publishing. 144 c.

Уэст, Дж. (2010) Макс Вебер в тени Антихриста: тезис Вебера и староверы // Частное предпринимательство в дореволюционной России: этноконфессиональная структура и региональное развитие, XIX - начало XX в. / отв. ред.: Б. В. Ананьич и др. М. : РОССПЭН. 549 с. С. 14-30.

Швецова, М. В. (1899) «Поляки» Змеиногорского округа // Записки Западно-Сибирского отдела Императорского Русского географического общества. Кн. 26. Омск : б. и. 112 с. С. 1-92.

Шитова, Н. И. (2012) Особенности культуры «стариковских» (старообрядцев) г. Горно-Алтайска // История и современность Республики Алтай: Материалы республиканской научно-исторической конференции / отв. ред. А. Н. Гавриков. Горно-Алтайск: б. и. 137 с. С. 68-71.

Щапов, А. П. (1862) Земство и раскол. СПб. : Товарищество «Общественная польза». 161 с.

Черных, А. В. (2007) «Крещенская» и «Спасовская» святая вода у часовенных старообрядцев Пермского Прикамья // Уральский исторический вестник. № 3 (17). С. 84-87.

Чистов, К. В. (2003) Русская народная утопия (генезис и функции социально-утопических легенд). СПб. : Дмитрий Буланин. 545 с.

Чудновский, С. Л. (1890) Раскольники на Алтае (выдержки из дневника) // Северный Вестник. № 9. С. 39-74.

Эткинд, А. М. (1998) Хлыст: секты, литература и революция. М. : Новое литературное обозрение. 685 с.

Эткинд, А. М. (2013) Внутренняя колонизация. Имперский опыт России. М. : Новое литературное обозрение. 448 c.

Anderson, B. (1991) Imagined Communities: Reflections on the Origin and Spread of Nationalism. London : Verso. $224 \mathrm{p}$.

Berzon, T. S. (2016) Classifying Christians: Ethnography, heresiology, and the limits of knowledge in Late Antiquity. Oakland : University of California Press. 302 p.

Bourdieu, P. (1991) Genesis and Structure of the Religious Field // Comparative Social Research. Vol. 13. P. 1-44.

Gerholm, T. (2003) Sweden: Central Ethnology, Peripheral Anthropology // Fieldwork and footnotes Studies in the history of European anthropology / ed. by H. F. Vermeulen, A. A. Roldán. Routledge : London \& New York. 261 p. P. $159-170$.

Jasiewicz, Z., Slattery, D. (2003) Ethnography and Anthropology: The Case of Polish Ethnology // Fieldwork and footnotes Studies in the history of European anthropology / ed. by H. F. Vermeulen, A. A. Roldán. London \& New York, Routledge.261 p. P. 184-201.

Paert, I. (2003) Old Believers, Religious Dissent and Gender in Russia, 1760-1850. Manchester, UK ; New York, NY : Manchester University Press. 257 p.

Rogers, D. (2009) The Old Faith and the Russian Land: a Historical Ethnography of Ethics in the Urals. Ithaca ; London : Cornell univ. press. $338 \mathrm{p}$.

Weber, M. (1997) The protestant ethic and the spirit of capitalism. London; New York : Routledge. 292 p.

Дата поступления: 28.05.2021 2.

\section{REFERENCES}

Adrianov, A. V. (1882a) Raskol'nich'i obshchiny v Sibiri [Old Belief Communities in Siberia]. Eastern Review, no. 37, pp. 11-15. (In Russ.).

Adrianov, A. V. (1882b) Raskol'nich'i obshchiny v Sibiri [Old Belief Communities in Siberia]. Eastern Review, no. 38, pp. 9-12. (In Russ.).

Adrianov, A. V. (1904) Ocherki Minusinskogo kraia [Essays on Minusinsk Krai]. Tomsk, Parovaia Tipo-litografiia P. I. Makushina. 61 p. (In Russ.). 
Anderson, V. M. (1908) Staroobriadchestvo i sektanstvo: istoricheskii ocherk russkogo religioznogo raznomysliia [Old Belief and Sectarianism: A Historical Essay on Russian Religious Dissent]. St. Petersburg, Tipografiia Pervoi Trudovoi Arteli. 460 p. (In Russ.).

Borovik, Yu. V. (2003) «Kamen’ pretykaniia» $\mathrm{i}$ «protivogosudarstvennyi raskol» (o strannikakh Permskoi gubernii v nachale XX v.) ["A stumbling block" and "A counter-state schism": On Wanderers (Stranniki) of Perm Governorate at the turn of the $20^{\text {th }}$ century]. Ural'skii sbornik. Istoriia. Kul'tura. Religiia [Uralic Miscellany. History. Culture. Religion], Iss. 5. Ed. by I. V. Pochinskaya. Ekaterinburg, Ural University. 344 p. Pp. 261-272. (In Russ.).

van Dijk, T. A. (2013). Diskurs i vlast': Reprezentatsiia dominirovaniia v iazyke i kommunikatsii [Discourse and Power. Contributions to Critical Discourse Studies]. Transl. from Engl. Moscow, Knizhnyi dom «LIBROKOM». 344 p.

Grebenshchikov, G. D. (1914). Altaiskaia Rus': istoriko-etnograficheskii ocherk [Altai Rus': a historical and ethnographical Essay]. In: Altaiskii al'manakh [The Altai Almanac] / ed. by G. D. Grebenshchikov. St. Petersburg, Zhizn' Altaia. 202 p.

Gupta, A. and Fergusson, J. (2013) Distsiplina i praktika: «pole» kak mesto, metod i lokal'nost'v antropologii [Discipline and Practice: The "Field" as Site, Method, and Location in Anthropology]. Ethnographic Review, no 6, pp. 3-44. (In Russ.).

Gur'ianova, N. S. (1988) Krest’ianskii antimonarkhicheskii protest v staroobriadcheskoi eskhatologicheskoi literature perioda pozdnego feodalizma [Peasant Antimonarchic Protest in Old Believer Eschatological Literature of Late Feudalism]. Novosibirsk, Nauka. 182 p. (In Russ.).

Zol'nikova, N. D. (2016) Dnevnik arkheograficheskoi gruppy N. N. Pokrovskogo 1967 g. [The 1967 journal of N. N. Pokrovsky's Archaeographic Group]. In: Uralo-Sibirskii paterik: teksty i kommentarii [The Ural-Siberian Patericon: texts and commentary] / ed. by N. N. Pokrovskii. Moscow, Publishing House IaSK. Book 2 (Vol. 3). 295 p. Pp. $153-193$ (In Russ.).

Zol'nikova, N. D. (2018) Polevoi dnevnik arkheograficheskoi gruppy N. N. Pokrovskogo (Tuva, 6-7 avgusta 1967 g.) [A field journal of N. N. Pokrovsky's Archaeographic Group: Tuva, 6-7 August 1967]. Bulletin of Irkutsk State University, vol. 23, pp. 152-157. (In Russ.).

Zol'nikova, N. D. (2001) Skitskie pis'ma vtoroi poloviny XX veka (Nizhnii Enisei) [Letters from sketes in the latter half of the $20^{\text {th }}$ Century (Lower Yenisei)]. In: Obshchestvennoe soznanie i literatura XVI-XX vv. [Public Consciousness and Literature of $16^{\text {th }}-20^{\text {th }}$ Centuries] / ed. by N. N. Pokrovsky. Novosibirsk, SO RAN. 381 p. Pp. 292-325. (In Russ.).

Kazantseva, T. G. (2014) «Monastyr’ Danilov, filippovskii tolk»: osobennosti dogmatiki staroverov iugo-zapadnykh raionov Kuzbassa [“Danilov Monastery, Filipp's Accord”: Particularities in Dogmatics of Old Believers of South-Western Kuzbass]. In: Dukhovnye stikhi v rukopisnykh sbornikakh staroobriadtsev filippovskogo soglasiia (po materialam Kemerovskogo territorial'nogo sobraniia GPNTB SO RAN) [Spiritual verses in manuscript collections by Old Believers of Filippovsky Accord (from the Kemerovo Territorial Collection of SPSTL SB RAS] / ed. by A. Yu. Borodikhin et al. Novosibirsk, GPNTB SO RAN. 363 p. Pp. 9-62. (In Russ.).

Kerov, V. V. (2010) Predprinimatel'stvo staroobriadtsev v Rossii [Entrepreneurship of Old Believers in Russia]. In: Chastnoe predprinimatel'stvo $v$ dorevoliutsionnoi Rossii: etnokonfessional'naia struktura i regional'noe razvitie, XIX - nachalo XX v. [Private Entrepreneurship in Prerevolutionary Russia: Ethnoconfessional Structure and Regional Development] / ed. by B. V. Ananich et al. Moscow, ROSSPEN. 549 p. Pp. 31-111. (In Russ.).

Kerov, V. V. (2016) “Se chelovek i delo ego...”: Konfessional'no-eticheskie faktory staroobriadcheskogo predprinimatel'stva ["Behold a Man and His Deed...": Confessional and Ethical Factors of Old Believer Entrepreneurship]. Moscow, Ekon-Inform. 590 p. (In Russ.).

Kon, F. Ia. (1914) Usinskii krai [Usinsky Krai]. Zapiski Krasnoiarskogo podotdela Vostochno-Sibirskogo otdela Imperatorskogo russkogo geograficheskogo obshchestva. Zapiski po geografii [Transactions of Krasnoyarsk Suboffice of Eastern Siberian Office of Imperial Geographical Society. Transactions on Geography], vol. 2., iss. 1.117 p.

Koroleva, E. V. (2012) Etnicheskaia samoidentifikatsiia Oimonskikh starozhilov po materialam avtobiograficheskikh vospominanii U. M. Argokovoi i S. I. Solonkinoi [Ethnic Self-Identification of Oimon Old-Timers from the Autobiographical Notes of U. M. Argokova and S.I. Solonkina]. In: Aktual'nye problemy istoricheskikh issledovanii: vzgliad molodykh uchenykh [Current Problems of Historical Research: A View of Young Researchers]: Proceedings and Materials of $2^{\text {nd }}$ All-Russian Youth Research Conference / ed. by R.E. Romanov. Novosibirsk, Nonparel’. 336 p. Pp. 318-324. (In Russ.).

Litvina, N. V. (2016) Religioznoe sosedstvo shortsev, chelkantsev i staroobriadtsev: stereotipy i vzaimodeistvie [Neighbouring faiths of the Shors, Chelkans and Old Believers: stereotypes and interactions]. Sibirskie Istoricheskie Issledovania, o. 1, pp. 59-73 (In Russ.).

Mal'tsev, A. I. (1996) Starovery-stranniki v XVIII - pervoi polovine XIX v. [Old Believers-Wanderers in $18^{\text {th }}$ and first half of the $19^{\text {th }}$ centuries]. Novosibirsk, Sibirskii khronograf. 266 p. (In Russ.).

Oshurkov, V. A. (1893) Iz stranstvovanii po zemle Uriankhov [From Journeys across the land of the Uriankhi]. Sibirskii sbornik [Siberian Miscellany], vol. 2, pp. 73-132. (In Russ.).

Pokrovskii, N. N. and Zol'nikova, N. D. (2002) Starovery-chasovennye na vostoke Rossii v XVIII-XX vv. : Problemy tvorchestva i obshchestvennogo soznaniia [Old believers of the Chasovennoye accord in the East of Russia in the 18th - 20th centuries: Problems of creativity and public consciousness]. Moscow, Pamiatniki istoricheskoi mysli. 471 p. (In Russ.). 
Putilov, N. A. (1885a) Usinskii krai [Usinskii krai]. Eniseiskie eparkhial'nye vedomosti [Yeniseisk Eparchial Records], no. 1, pp. 7-12. (In Russ.).

Putilov, N. A. (1885b) Usinskii krai [Usinskii krai]. Eniseiskie eparkhial'nye vedomosti [Yeniseisk Eparchial Records], no. 5, pp. 72-76. (In Russ.).

Putilov, N. A. (1885c) Usinskii krai [Usinskii krai]. Eniseiskie eparkhial'nye vedomosti [Yeniseisk Eparchial Records], no. 9. pp. 163-169. (In Russ.).

Putilov, N. A. (1885d) Usinskii krai [Usinskii kraii]. Eniseiskie eparkhial'nye vedomosti [Yeniseisk Eparchial Records], no. 12, pp. 217-219. (In Russ.).

Putilov, N. A. (1885e) Usinskii krai [Usinskii krai]. Eniseiskie eparkhial’nye vedomosti [Yeniseisk Eparchial Records], no. 16, pp. 289-294. (In Russ.).

Putilov, N. A. (1885f) Usinskii krai [Usinskii krai]. Eniseiskie eparkhial'nye vedomosti [Yeniseisk Eparchial Records], no. 19-20, pp. 328-332. (In Russ.).

Raskov, D. E. (2012) Ekonomicheskie instituty staroobriadchestva [Economic institutions of the Old Believers]. St. Peterburg, SPbGU. 343 p. (In Russ.).

Rygovskiy, D. S. (2019a) Eniseiskie i shorskie starovery: slozhnaia struktura «prostogo» soobshchestva [Old Believers of the Yenisei and Shoriya: A complex structure of a "simple" community]. New Research of Tuva, no 1, pp. 60-74. (In Russ.). DOI: https://doi.org/10.25178/nit.2019.1.5

Rygovskiy, D. S. (2019b) Vliianie religioznykh praktik na sotsial'nuiu strukturu eniseiskikh staroverov [The Influence of Religious Practices on the Social Structure of Yenisei Old Believers]. Antropologicheskii forum, no. 41, pp. 11-35. (In Russ.). https://doi.org/10.31250/1815-8870-2019-15-41-11-35

Rygovskiy, D. S. (2019c) Mekhanizmy razlicheniia v srede sibirskikh staroverov [Mechanisms of Differentiation among Siberian Old Believers]. In: Iazyk, kniga i traditsionnaia kul'tura pozdnego Russkogo srednevekov'ia $v$ nauke, muzeinoi $i$ bibliotechnoi rabote [Language, Book and Traditional Culture of Late Russian Middle Ages in Research, Museum and Library Work]: Proceedings of 4th International Research Conference / comp. by Yu. S. Beliankin, E. V. Vorontsova and N. V. Litvina. Moscow, MGU. 781 p. Pp. 728-737. (In Russ.).

Sokolovskii, S. V. (2012) Sotsiologiia vs. antropologiia: zapozdalye zametki na poliakh k diskussii «fiziki vs. liriki» [Sociology vs. Anthropology: Overdue Notes in the Margins of the "Physicists" vs. "Lyricists" discussion]. Antropologicheskii Forum, no. 16, pp. 130-139. (In Russ.).

Tatarintseva, M. P. and Mollerov, N. M. (2016) Russkie v Tuve (konets XIX - pervaia polovina XX v.) [Russians in Tuva in late 19th and the first half of 20th centuries]. Novosibirsk, Nauka. 295 p. (In Russ.).

Tatarintseva, M. P. and Storozhenko, A. A. (2015) Staroobriadtsy Tuvy: retrospektiva i sovremennost' [The Old Believers of Tuva: the past and present]. Saarbrucken: Lambert Academic Publishing. 137 p. (In Russ.).

West, J. (2010) Maks Veber v teni Antikhrista: tezis Vebera i starovery [Max Weber in the shadow of Antichrist: Weber's thesis and Old Believers]. In: Chastnoe predprinimatel'stvo $v$ dorevoliutsionnoi Rossii: etnokonfessional'naia struktura $i$ regional'noe razvitie, XIX - nachalo XX v. [Private Entrepreneurship in Prerevolutionary Russia: Ethnoconfessional Structure and Regional Development] / ed. by B. V. Ananich et al. Moscow, ROSSPEN. 549 p. Pp. 14-30. (In Russ.).

Shvetsova, M. V. (1899) «Poliaki» Zmeinogorskogo okruga [The "Poles” of Zmeinogorsk District]. In: Zapiski ZapadnoSibirskogo otdela Imperatorskogo Russkogo geograficheskogo obshchestva [Transactions of Western Siberian Office of Imperial Geographical Society]. Book 26. Omsk, s. n. 112 p. Pp. 1-92. (In Russ.).

Shitova, N. I. (2012) Osobennosti kul'tury «starikovskikh» (staroobriadtsev) g. Gorno-Altaiska [Features of the culture of 'Starikovskie' (Old Believers) in Gorno-Altaisk]. In: Istoriia i sovremennost' Respubliki Altai: Materialy respublikanskoi nauchno-istoricheskoi konferentsii [History and Contemporaneity in the Republic of Altai: Proceedings of the Republican Research Conference in History]. Ed. by A. N. Gavrikov. Gorno-Altaisk, s. n. 137 p. Pp. 68-71. (In Russ.).

Shchapov, A. P. (1862) Zemstvo i raskol [The Zemstvo system and the Schism]. St. Petersburg, Tovarishchestvo «Obshchestvennaia pol'za». 161 p. (In Russ.).

Chernykh, A. V. (2007) «Kreshchenskaia» i «Spasovskaia» sviataia voda u chasovennykh staroobriadtsev Permskogo Prikam'ia [The "Epiphany” and “Savior” Holy Water among the Chasovennye Old Believers of Perm Kama region]. Ural'skii istoricheskii vestnik [Ural Historical Journal], no 3 (17), pp. 84-87. (In Russ.).

Chistov, K. V. (2003) Russkaia narodnaia utopiia (genezis i funktsii sotsial'no-utopicheskikh legend) [Popular Utopia in Russia: The Genesis and Functions of Social Utopian Legends]. St. Petersburg, Dmitrii Bulanin. 545 p. (In Russ.).

Chudnovskii, S. L. (1890) Raskol'niki na Altae (vyderzhki iz dnevnika) [Old Believers in the Altai: Excerpts from a journal]. Severnyi Vestnik, no 9, pp. 39-74. (In Russ.).

Etkind, A. M. (1998) Khlyst: sekty, literatura i revoliutsiia [The Khlyst: Sects, Literature, and Revolution]. Moscow, Novoe literaturnoe obozrenie. $685 \mathrm{p}$.

Etkind, A. M. (2013) Vnutrenniaia kolonizatsiia. Imperskii opyt Rossii [Internal Colonization: Russia's Imperial Experience]. Moscow, Novoe literaturnoe obozrenie. 448 p. (In Russ.).

Anderson, B. (1991) Imagined Communities: Reflections on the Origin and Spread of Nationalism. London: Verso. 224 p. 
Berzon, T. S. (2016). Classifying Christians: Ethnography, heresiology, and the limits of knowledge in Late Antiquity. Oakland, University of California Press. 302 p.

Bourdieu, P. (1991) Genesis and Structure of the Religious Field. Comparative Social Research, vol. 13, pp. 1-44.

Gerholm, T. (2003) Sweden: Central Ethnology, Peripheral Anthropology. Fieldwork and footnotes Studies in the history of European anthropology / ed. by Han F. Vermeulen and Arturo Alvarez Roldán. Routledge: London \& New York, pp. $159-170$.

Jasiewicz, Z. and Slattery, D. (2003) Ethnography and Anthropology: The Case of Polish Ethnology. In: Fieldwork and footnotes Studies in the history of European anthropology / ed. by Han F. Vermeulen and Arturo Alvarez Roldán. London \& New York, Routledge. 261 p. Pp. 184-201.

Paert, I. (2003) Old Believers, Religious Dissent and Gender in Russia, 1760-1850. Manchester, UK; New York, NY, Manchester University Press. 257 p.

Rogers, D. (2009) The Old Faith and the Russian Land: a Historical Ethnography of Ethics in the Urals. Ithaca; London: Cornell univ. Press. 338 p.

Weber, M. (1997) The protestant ethic and the spirit of capitalism. London; New York, Routledge. 292 p.

Submission date: 28.05.2021. 